How to Cite

Srivastava, S., \& Mishra, S. K. (2019). Critical study of Indian and french philosophical literature: in search of wisdom, spirituality and rationalism. International Journal of Social Sciences, 2(1), 1-3. https://doi.org/10.31295/ijss.v2n1.48

\title{
Critical Study of Indian and French Philosophical Literature: In Search of Wisdom, Spirituality and Rationalism
}

\author{
Srashti Srivastava \\ Amity University, Lucknow, India \\ Corresponding author email: ssrivastava8@lko.amity.edu
}

\author{
Satendra Kumar Mishra \\ Amity University, Lucknow, India \\ skmishra2@lko.amity.edu
}

\begin{abstract}
The Indian philosophy is enriched with incredible, spiritual wisdom. Indian history is full of examples where the literature was specially designed to promote "the aim of life". The French literature is known more for its romanticism in the medieval times, pre or post renaissance whereas the Indian literature reflects spiritual romanticism. To begin with the French literature, we found an influence of Granada on the French spiritual literature. It is often said that probably there is no spiritual French writer who has not read Granada, especially of the 17th century. Based on our initial research, we found that French literature is blessed with extraordinary French philosophers. The wisdom in the French literature in fact worked as a catalyst in French enlightenment. Shruti, as per the Indian mythology are the words of god passed on to the mortals and spread verbally through generations. The four Vedas come under this category. Smriti means the literature which must be remembered after listening or reading and can be written. The works like Upanishads, Brahmanas and Puranas come under this category. The very essence of the Indian philosophical wisdom is to transform the metaphysical agony into spiritual peace.

Keywords---wisdom, Granada, mythology, metaphysical, Shruti.
\end{abstract}

\section{Introduction}

The Indian and the French literature are full of literary examples of wisdom. Starting from the mythological stories of Ramayan and Mahabharat, the gradual enrichment of Indian literature with literary wisdom is clearly visible. From Panchtantra of Vishnu Sharma to legendary Premchand and from Chanson de Roland to Guy de Maupassant, brilliant similarities are found between both. In both the literature, the writers presented a note of wisdom as a hidden message for the readers. The literature of both is enriched with the description of the ideal societal norms, ethics, values and philosophy of life.

On one side, where the French literature is known more for its romanticism in the medieval times, pre or postrenaissance, the Indian literature reflects spiritual romanticism. The world danced on the tunes of the spiritual romance of Kalidas. The literary world was stunned with the spiritual presence of the then known materialistic love by Meghadutam and Kumar Sambhav. Our thesis is on the acknowledged similarities in both the literature among these similarities our focus will be on the parameters of spiritual wisdom (Thapar, 2015), Thomson, 1962), \& Young, 2017).

\section{Research Methodology}

In this research paper, we have used biographical and historical approach. Our primary sources have been mostly books available in the Amity University library. We have also collected data from the National archives of India. 


\section{Result and Analysis}

To begin with the French literature, we found an influence of Granada on the French spiritual literature. It is often said that probably there is no spiritual French writer who has not read Granada, especially of the $17^{\text {th }}$ century. Based on our initial research, we found that French literature is blessed with extraordinary French philosophers. The wisdom in the French literature in fact worked as a catalyst in French enlightenment (Halton, 1977). The French philosophers like Montesquieu (the spirit of laws), Jean-Jacques Rousseau (the social contract), John Locke (the two treatises of government) and Voltaire, the essayist, did not within themselves brought the enlightenment but it was the 'wisdom' which was strong enough to dismantle 'the divine theory of kingship'.

Ponting (1993), Raychaudhuri (1936), Tattwananda (1984), it is the power of French wisdom that Rousseau dared to raise his voice against the unchallenged divine rights and promoted the new revolutionary theory of 'Social Contact'. By the 'Two treatises of government,' John Locke enriched the French wisdom by the idea of division of power. The American constitution is based on this book only. In the same way, Indian literature is also full of wisdom since the genesis of Aryan literature. Shruti and Smriti literature provided the philosophical base to the Indian spiritual romanticism.

Shruti, as per the Indian mythology are the words of god passed on to the mortals and spread verbally through generations. The four Vedas come under this category. Smriti means the literature which must be remembered after listening or reading and can be written. The works like Upanishads, Brahmanas, and Puranas come under this category (Thomson, 1999). The very essence of the Indian philosophical wisdom is to transform the metaphysical agony into spiritual peace which comes in the form of the cascade, free of age, sex, and individuality.

As per the topic of research, French wisdom can also be seen in the works of Pierre Belle, Denis Diderot, and François Quesnay. Belle was a contemporary of Louis IV. He was impressed by the philosophy of René Descartes. His works reflect rationalism and logical thinking. He criticized the orthodox nature of the then clergies who tried to identify God's boon or bane in each and every natural incident. This was done deliberately to make Christianity complex and assert the importance of the clergies. For example, a comet was seen in December 1680 and the Christian clergies tried to manipulate the situation as an inauspicious occasion and a symbol of wrath of God. Belle gave a rational explanation and logically proved that the visibility of comet was a natural process. This is one of the classical examples of French wisdom (Chandra \& Gupt, 1967). "Historical and cultural dictionary", a book of Belle was published in 1697 in which he presented a political analysis of the philosophy of life of not only the Scientists but also the Historians, Philosophers, and Theologians.

One more French writer of importance is Denis Diderot (1713-1784). Diderot is most famous for the publication of encyclopedia published in 28 volumes in 1772. Although more than 2000 people and Jean le Rond d'Alembert associated with him in completing it.

This work (encyclopedia) added glory in already famous wisdom of the French literature. This was not only a compilation of data but the critical analysis of polity, religion, science and different contemporary subjects. Diderot dared to highlight the corruption involved in the then political system. He also raised questions on the authority of the church and criticized the unethical lifestyle of the papal community. He was alleged of the treason which resulted in his escape from France. Diderot can be logically and truly called the pioneer of revolutionary ideas (Pandey, 1972).

Bhandarkar (1987), Jain ET AL., (2017), Kumar (1999), Lough (1982), François Quesnay, as we all know that French history is enriched with innumerable intellectual philosophers and it is actually like searching a pearl in the ocean but we have given our best to identify few pearls successfully. We have deliberately avoided the famous writers like Rousseau, Voltaire, Montesquieu, etc... as much research has come out on these. We don't claim that the philosophers who are the part of our research are less known but we have tried to select less famous amongst the most (Thapar, 2002).

Following the lines of Belle and Diderot, one of the philosophers, thinker and physiocrat are François Quesnay. Till the middle of the $18^{\text {th }}$ century, economics did not have a separate identity. The economy was used as supporting articles and pillars for Political Science. François Quesnay was basically a physician but he is known for his works on economics. According to his economic principles, the source of money is not trade but nature. Those commodities which are being used for trade are basically provided by nature. He was probably the first economist who stressed on the importance of nature, the revival of land and sustainable exploitation of resources. This was indeed and spiritual wisdom in the then time (Raychoudhary, 1989). He criticized excessive revenue collection from the peasants. This principle was indeed a direct question on the authority ofthe monarch. His principles were famous throughout Europe and inspired many future economists. Adam Smith was one of those who became famous after being inspired by Quesnay. His wealth of nations published in 1776 made him the father of economy (Dev, 2009). 
Just like France, it is also tough to identify and work on any group of selected writers but still, we have tried to identify few.

One of them was Henry Louis Vivian Derozio (1809-1831). He was the leader of the Young Bengal Movement. $\mathrm{He}$ also published a newspaper named Hesperus. He focused on the moral development of the youth to prepare themselves for the freedom struggle. He was inspired by the three historical words of the French Revolution i.e. liberty, equality, and fraternity. He openly criticized the meaningless customs and rituals which had made the society shallow. He advocated the rights of woman and active involvement of youth in the nation-building process. His followers were called Derozians and the famous historian S.N. Banerjee has rightfully called him "the pioneer of modern civilization of Bengal" (Bhandarkar, 1995). Spiritual thought and wisdom can be easily observed in the works of Derozio.

Any discussion on spiritual wisdom is incomplete without the reference of Swami Vivekanand. Narendra Nath, as he was named before he asked for 'Vivek' from Goddess Kali (Mythology) under the guidance of Ram Krishna Paramhansa. He was the one who started to arouse the youth of India morally and ethically. According to his philosophy its, not the nation which will develop the youth into a resource but it's the youth of a nation who has to be morally strong enough to utilize the resources of the nation for its development.

\section{Conclusion}

The French wisdom was undoubtedly the reflection of the suppressed voice of the common people. Those commoners who were exploited by excessive taxation and no representation in the policy-making process. This wisdom became spiritual when more and more working class got involved in the legislation. The French philosophy brought a major shift in the spiritual paradigm of the French.

In the same way, Indian philosophy is enriched with incredible, spiritual wisdom. Indian history is full of examples where the literature was specially designed to promote "purusharth" which means "the aim of life" (Tattwananda, 1984). The ancient Indian society was completely based on this very parameter of life. Indian soil was blessed with infinite philosophers and rational thinkers who put forward a different metaphysical thought about life and life after death.

\section{Acknowledgments}

We are very much thankful to all our well-wishers who contributed and took out their valuable time in providing us inputs and suggestions.

\section{References}

Bhandarkar, R. G. (1987). Vaisnavism, Saivism and minor religious systems. Asian educational services. https://doi.org/10.1177\%2F000944559903500310

Jain, P., Agarwal, R., Billaiya, R., \& Devi, J. (2017). Women education in rural India. International Journal of Social Sciences and Humanities, 1(1), 21-26. https://doi.org/10.29332/ijssh.v1n1.12

Kumar, B. K. (1999). China and Japan in Indian Publications: A Bibliographic Survey, 1997-98. China Report, 35(3), 359-392.

Lough, J. (1982). The Philosophes and post-revolutionary France. Oxford: Clarendon Press.

Ponting, C. (1993). A green history of the world. The environment and the collapse of great civilizations.

Raychaudhuri, H. (1936). Materials for the Study of the Early History of the Vaishnava Sect. University of Calcutta.

Tattwananda, S. (1984). Vaisnava Sects, Saiva Sects, Mother Worship. Firma KLM.

Thapar, R. (2015). The Penguin history of early India: from the origins to AD 1300. Penguin UK.

Thomson, D. (1962). Europe Since Napoleon. Longman.

Young, S. (2017). Postwar: A history of Europe since 1945. Macat Library. 